\title{
Case and Grammatical Relations
}

\section{Citation}

Polinsky, Maria, and Omer Preminger. 2014. Case and Grammatical Relations. In Routledge Handbook of Syntax, ed. Andrew Carnie, Dan Siddiqi, and Yosuke Sato, 150-166. New York:

Routledge.

\section{Published Version}

http://www.routledge.com/books/details/9780415533942/

\section{Permanent link}

http://nrs.harvard.edu/urn-3:HUL.InstRepos:34222821

\section{Terms of Use}

This article was downloaded from Harvard University's DASH repository, and is made available under the terms and conditions applicable to Open Access Policy Articles, as set forth at http:// nrs.harvard.edu/urn-3:HUL.InstRepos:dash.current.terms-of-use\#OAP

\section{Share Your Story}

The Harvard community has made this article openly available.

Please share how this access benefits you. Submit a story.

Accessibility 


\title{
Case and Grammatical relations
}

\author{
Maria Polinsky and Omer Preminger
}

(Harvard University and Syracuse University)

\begin{abstract}
This chapter discusses the notions of morphological (surface) case and abstract Case, showing the empirical and theoretical motivation for each. The discussion of morphological case presents the dimensions of cross-linguistic variation found in this domain, and outlines the main tendencies in the expression of case. The notion of abstract Case is used to predict the distribution of overt and non-overt nominal forms, and is considered one of the fundamental abstract syntactic relations in linguistic theory. The chapter presents a brief survey of theoretical approaches to Case in formal grammar and then discusses the main ways of modeling Case in nominative-accusative and ergative languages.
\end{abstract}

\section{Morphological case, abstract Case, and the need for Case Theory}

Certain constituents in clause structure are known to determine the form and/or position of other clausal constituents. In particular, verbs and adpositions determine the morphological form of their associated nouns. For example, in the Latin $(1 \mathrm{a}, \mathrm{b})$, the form of the noun 'eyes' depends on the preposition that it appears with, varying between accusative and ablative: 
(1) a. ante ocul-ōs

before eye-ACC.PL

b. de ocul-is

from eye-ABL.PL

The alternation in the form of a nominal or adjectival constituent based on its function is captured under the label "case". Generative grammar and related formalisms recognize two kinds of case: morphological and abstract. We will explore each of these notions in turn. Although the two versions of case are quite distinct, they both appeal to the basic insight that nominals occurring in particular forms (cases) should be identified with distinct phrase-structural configurations.

Morphological case is a category that reflects the relationship between a head and its dependent noun(s), or between different nouns in a clause. Taken to the next level of abstraction, the position/form exhibited by a nominal constituent in a clause is determined by its syntactic configuration. Traditional grammars appeal to a one-to-one mapping from case to function: from nominative case to the grammatical function of sentential subject, from accusative case to the grammatical function of direct object, etc. This one-to-one mapping (abstracting away, for the moment, from certain empirical inadequacies it faces) can be more accurately expressed as a correspondence between the grammatical function of a nominal constituent and its morphological marking. 
The apparent empirical variation in morphological case can be constrained along at least three dimensions: variation in the expression of core arguments; overt vs. covert expression of case; and a distinction between argument and adjunct cases.

Cross-linguistic accounts of the variation in case marking among core arguments employ three argument-structural primitives: S-the sole argument of a one-place verb; $\mathrm{A}$ - the agent or most agent-like argument of a two-place verb, and $\mathrm{P}$ - the theme (patient) or most patient-like argument of a two-place verb (Comrie 1978, 1989; Dixon 1994; among others). The three most common morphological case systems are "accusative", "ergative", and "neutral". Case systems where S and A are marked alike and contrast with P are known as "accusative"; such systems are well known from Latin, Greek, and the Balto-Slavic languages. This system is illustrated in (2), for Russian, and (3), for the Cushitic language Harar Oromo. The Russian example illustrates the cross-linguistically typical nominative-accusative pattern; Harar Oromo instantiates a morphologically less-frequent pattern where the nominative is overtly marked, but the accusative is not.

(2) a. starušk-a odnaždy s bazara prišla $\quad$ Russian old_woman-NOM once from market-GEN came

'The old woman once came back from the market.'

b. kot zametil starušk-u

cat.NOM noticed old_woman-ACC

'The cat noticed the old woman.' 
$\begin{array}{llll}\text { (3) a. níití-n } & \text { magaláa } & \text { xéesá meesháa } & \text { Harar } \\ \text { woman-NOM } & \text { market } & \text { inside things.ACC } & \text { Oromo } \\ \text { náa-f } \quad \text { gurgur-t-e } & & \\ \text { me-DAT sold-FEM-TENSE } & & \end{array}$

'The woman inside the market sold goods for me.' (Owens 1985: 86)

b. núitíi-n magaláa deeme

woman-NOM market went

'The woman went to the market.' (Owens 1985: 56)

c. pro níitíi taná arke

woman.ACC this saw

'He saw this woman.' (Owens 1985: 225)

Case systems where S and P are marked alike and contrast with A are known as "ergative"; morphologically ergative languages include Basque, Georgian, Tongan, or Chukchi, illustrated in (4).
(4) a. keyy-e
วtlPəg-ən
təm-nen
Chukchi
bear-ERG man-ABS kill-AOR.3SG:3SG
'The bear killed the man.'
b. ətl?əg-ən ret-g?e
man-ABS arrive-AOR.3SG
'The man arrived.' 
In a "neutral" case system, the overt marking does not distinguish between S, A, and P: the surface form of a noun does not change depending on whether it is, e.g., a subject or an object (this is the case for English outside of the pronominal system). Overt case marking is absent in Mandarin, Thai, Vietnamese, and all or most creole languages. In derivational approaches to grammar, the presence or absence of surface case marking is considered a matter of parametric variation (cf. Ouhalla 1991). ${ }^{1}$ However, beyond isolating morphology, it is not yet clear what other features of language design correlate with the absence of overt case marking.

Finally, "tripartite" or "contrastive" systems are those where S, A, and P all have different case marking, as in Antekerrepenhe (Arandic; Central Australia):

(5) a. arengke-le aye-nhe ke-ke Antekerrepenhe dog-A me-P bite-PAST

'The dog bit me.'

b. athe arengke-nhe we-ke me:A dog-P strike-PAST 'I hit the dog.'

c. arengke-ø nterre-ke dog-S run-PAST

'The dog ran.' (Bittner and Hale 1996: 4)

The accusative, ergative, neutral, and tripartite case systems are often referred to as different alignments, and have received significant attention in the typological literature (Silverstein 1976;

\footnotetext{
${ }^{1}$ We take the notion of parametric variation to include variation in lexical properties of functional categories. There is a stronger position, found in the generative literature, that takes all
} 
Comrie 1989, among others). Much of the theoretical interest surrounding alignment systems has to do with the correlation between case and agreement (see section 3), the notion of splits (cf. Coon 2013a, b and references therein), and the differences in abstract Case assignment between accusative and ergative systems (Aldridge 2004; Legate 2002, 2008).

The number of distinct overt cases in a single language may vary significantly; one extreme is represented by languages with no morphological case marking whatsoever, while at the other extreme, one finds languages with extremely rich case systems, such as Uralic, Dravidian, or Nakh-Dagestanian. Iggesen (2011) finds the distribution of morphological cases shown in Table 1 in his language sample.

Table 1. Surface case-marking across languages

\begin{tabular}{|l|l|}
\hline No morphological case-marking & 100 languages \\
\hline 2 cases & 23 languages \\
\hline 3 cases & 9 languages \\
\hline 4 cases & 9 languages \\
\hline $5-7$ cases & 39 languages \\
\hline 10 or more cases & 23 languages \\
\hline
\end{tabular}

The Nakh-Dagestanian languages represent perhaps the furthest extreme among rich case systems; some languages in this family appear to have fifty cases or more (Comrie and Polinsky 1998). However, even in such case-rich languages, the number of argument cases is predictably 
small: the case(s) of subject, object, possessor, and indirect object (Blake 2001). The majority of other forms are represented by locative (adjunct) cases, which encode location and direction (Comrie and Polinsky 1998.). Setting such adjunct cases aside, we can describe the availability of morphological cases within a given language by the following implicational hierarchy (cf. Blake 2001 for a similar formulation):

(6) subject case/object case $>$ possessor (genitive) case $>$ indirect object (dative) case

Linguistic theory has gone beyond viewing case as a purely morphological phenomenon by extending the idea of dependency in a more general way. The notion of abstract Case can be used to predict the distribution of both overt and non-overt nominal forms, and may thus be thought of as one of the fundamental abstract syntactic relations in the mental grammar. Vergnaud's conjecture, expressed in his 1977 letter to Chomsky advocating the principle of abstract Case, was an important step in the development of the idea. As summarized by Lasnik,

"Vergnaud's now very familiar basic idea was that even languages like English with very little case morphology pattern with richly inflected languages in providing characteristic positions in which NPs with particular cases occur.” (Lasnik 2008: 18)

We defer the discussion of the actual modeling of Case assignment to section 3; in section 2, we address the main motivations for positing abstract Case.

\section{Abstract Case}


Abstract Case (which we will refer to simply as Case ${ }^{2}$, below) is a primitive feature that reflects a relationship between an argument and its syntactic context; in other words, the assignment of abstract Case is determined by syntactic structure. The principles of Case assignment were grouped under the rubric of Case Theory, which included the following components:

(7) Case Uniqueness Principle: A lexical NP may receive only one Case

(8) Case Filter: Every lexical NP must be assigned Case (Chomsky and Lasnik 1977, Vergnaud 1977/2008)

(9) Principle of Case licensing: Every instance of Case must be properly licensed

The Uniqueness Principle (7) correctly rules out such forms as English *my's, where the form $m y$ receives the inherent lexical genitive, and is then assigned the genitive again via ' $s,{ }^{3}$ but incorrectly rules out the case stacking such as the stacking of dative and accusative in Korean, illustrated in (10c).

$\begin{array}{lllll}\text { a. } & \text { haksayng-tul-i } & \text { ton-i } & \text { philyohata } & \text { Korean } \\ & \text { student-PL-NOM } & \text { money-NOM } & \text { need } \\ \text { b. } & \text { haksayng-tul-eykey } & \text { ton-i } & \text { philyohata } \\ & \text { student-PL-DAT } & \text { money-NOM } & \text { need }\end{array}$

${ }^{2}$ Distinguished from morphological case marking by the capital $\mathrm{C}$ in its name.

${ }^{3}$ One could argue that the inner DP in * $m y$ 's is in fact genitive even before the possessive ' $s$, which can be seen from examples such as a car of yours/hers/theirs. Then one could contend that *my's exists in English, but as an irregular form: mine. 


c. haksayng-tul-eykey-ka ton-i $\quad$ money-NOM need
student-PL-DAT-NOM $\quad$ mohata
'Students need money.' (Gerdts and Youn 1988: 160; Schütze 2001: 194)

The condition in (7) remains controversial and a number of researchers have argued that it may need to be relaxed (cf. McCreight Young 1988; Bejar and Massam 2002; Richards 2013, among others), but we will not discuss the more complex issues of multiple case assignment (or "casestacking") here.

The Case Filter (8) accounts for the ill-formedness of examples such as (11), where the nominals book and editor have not received the appropriate genitive case:

(11) $*[[$ the book $]$ editor $]$ insistence on completing the work

To understand the Case Filter better, we need to recognize two types of positions where nominals can occur: Cased and Caseless positions. The contrast between these two types of positions is correlated with the contrast between lexical DPs on the one hand, and all other complements (sentential complements and empty categories) on the other. ${ }^{4}$ Lexical DPs can only appear in Cased positions; Caseless DPs therefore have to move to a position where they can receive Case. To see an application of the Case Filter, consider the following examples, where expect can take either a nominal or a sentential complement:

\footnotetext{
${ }^{4}$ Throughout this chapter, we use the label "DP" (Determiner Phrase) to refer to the maximal projection of a nominal, except when quoting directly from sources that use a different label. As far as we can tell, though, nothing stated here hinges on this particular choice.
} 
(12) Everybody expected this rough patch.

(13) Everybody expected that this rough patch was going to come.

Both types of complements can appear as subjects of the corresponding passive clauses:

(14) This rough patch $_{i}$ was generally expected $t_{i}$.

(15) [That this rough patch was going to come $]_{i}$ was generally expected $t_{i}$.

However, only sentential complements are possible in the impersonal passive (with the expletive it):

(16) *It was generally expected this rough patch.

(17) It was generally expected [that this rough patch was going to come].

The contrast between (16) and (17) is explained in terms of Case. Sentential complements do not receive Case and can therefore appear in Caseless positions. In contrast, the DP a rough patch has to receive Case; the addition of the passive morphology to expect renders its complement position Caseless, so leaving a rough patch in this position violates the Case Filter.

Like passive verbs, predicative adjectives that take sentential complements are unable to Case-mark their complements. This means that their DP complements are Caseless and result in ill-formed structures (19). Such a structure can be rescued if the DP a victory moves to the subject position to receive Case (20): 
(18) It is unlikely [that we will win].

(19) *It is unlikely [a victory].

(20) $\quad[\text { A victory }]_{i}$ is unlikely $t_{i}$.

A strong argument in favor of the Case Filter comes from the conditions on lexical/overt subjects of infinitival clauses. ${ }^{5}$ In English, lexical subjects of infinitivals can be assigned Case in situ by the complementizer for:
a. $\quad[$ For him $/ *$ he to admit such a thing $]$ is impossible.
b. It is impossible [for him/*he to admit such a thing].

The complementizer for assigns objective case, as shown by the form of the pronoun in $(21 \mathrm{a}, \mathrm{b})$. The presence in $(21 a, b$,$) of objective case on what is clearly a subject illustrates the sort of$ problem one encounters when seeking a precise one-to-one mapping between grammatical functions (e.g. SUBJECT, OBJECT) and case markings (e.g. nominative, accusative/objective). In practice, these alignments are often imperfect.

While (21) exhibits an overt prepositional complementizer, in many other languages, covert complementizers may assign objective Case to infinitival subjects as well. Consider the following Russian sentence, in which the silent interrogative complementizer assigns dative case to the subject of the infinitive:

\footnotetext{
${ }^{5}$ In what follows, we will concentrate on English, but see Szabolcsi (2009), who shows that, in Hungarian, infinitival complements of subject control verbs and subject raising verbs can host overt nominative subjects.
} 


$$
\begin{aligned}
& \text { [Comp INTERR Maš-e/*Maš-a [prixodit’ segodnja]]? Russian } \\
& \text { Masha-DAT/*Masha-NOM come.INF today }
\end{aligned}
$$

'Should Masha come today?'

Without the complementizer, the overt infinitival subject is impossible: ${ }^{6}$

(23) *It is impossible [him to admit this]

$\begin{array}{lll}\text { *Maš-e } & \text { prixodit' } & \text { segodnja } \\ \text { Masha-DAT } & \text { come.INF today } & \\ \text { ('Masha should come today.'-declarative) } & \end{array}$

Recall that the Case Filter (8) applies to lexical DPs, but not to empty categories. Thus, in the following examples, the infinitival clause is licit with a non-lexical subject, PRO:

(25) [PRO to admit such a thing] is impossible.

(26) It is impossible [PRO to admit such a thing].

As the only item not subject to the Case Filter, PRO is in near-complementary distribution with overt subjects (cf. Radford 2004). ${ }^{7}$ Furthermore, since it is not able to receive objective case,

\footnotetext{
${ }^{6}$ Russian does allow declarative sentences with dative subjects, but not with the meaning intended in (24); such root infinitive constructions require the interpretation that the event is beyond the main participant's control. See Moore and Perlmutter 2000, Sigurđsson 2002, and references therein.
} 
PRO is incompatible with the Case-assigning complementizer for (although see, for example, Bobaljik and Landau 2009 and references therein, for empirical challenges to this approach): ${ }^{8}$

(27) *It is impossible [for PRO to admit such a thing]

In some contexts, however, lexical/overt subjects of infinitival complements are able to occur in either the presence or absence of for:

(28) They want [for him to succeed]

(29) They want [him to succeed]

${ }^{7}$ The complementarity between PRO and lexical/overt DPs is incomplete because of cases like (i), where neither PRO nor any other DP can appear in the underlined position (without of):

(i) Kim is fond Within the Government \& Binding framework, this imperfect complementarity was handled by subjecting PRO not to the precise inverse of the Case Filter, but to the PRO Theorem, which stated that PRO cannot tolerate syntactic government in general (even government by non-caseassigners).

${ }^{8}$ Note, however, that some English dialects, most notably Belfast English (Henry 1995: Ch. 1, 4), seem to have reanalyzed for as a complementizer that cliticizes to the infinitival marker $t o$. Accordingly, Belfast English allows constructions such as (i), (ii):

(i) For to stay here would be just as expensive.

(ii) I don't like the children for to be late. 
Case in (28) is assigned by the complementizer for, and the derivation is straightforward, with the Case Filter observed. However, Case on him in (29) has to be assigned some other way. A correlate of this difference is that in (29), unlike in (28), the verb want cannot be separated from him by intervening lexical material (Postal 1974):

(30) I have wanted all my life for him to succeed

(31) *I have wanted all my life him to succeed

The obligatory adjacency between want and him indicates that the latter can only receive Case from want under special conditions, namely when there is no separation between the two. If an adverbial phrase intervenes, as in (31), such Case assignment is blocked; at the same time, the lexical DP cannot receive Case from within the infinitival clause, and the result is ungrammatical (29). The Case assignment configuration illustrated in (29) is known as Exceptional Case Marking (ECM). The subset of English verbs that allow this configuration are referred to as ECM predicates (e.g., want, expect, find, prove, judge). The phenomenon of exceptional case assignment across an infinitival clause boundary is closely related to the accusativus cum infinitivo construction found in classical languages such as Latin, cf.:

$\begin{array}{llllll}\text { hodie necesse } & \text { est } & \text { te } & \text { solum } & \text { ambulare } & \text { Latin } \\ \text { today necessary } & \text { is } & \text { 2SG.ACC } & \text { alone.ACC } & \text { walk.INF }\end{array}$

'It is necessary for you today to walk alone.' 
Certain questions on the topic of Case theory remain to be addressed, concerning both the range of categories that can assign Case and the manner in which Case is assigned. We have already observed that both $\mathrm{C}$ heads (cf. English for) and certain prepositions may have Case-assigning properties; we have also tacitly assumed that verbal and inflectional heads can act as Case assigners (verbs assign Case to their complements; inflectional heads assign Case to clausal subjects). One of the most intriguing aspects of Case Theory concerns the general principles that regulate the situations in which Case assignment is and is not possible. What prevents particular lexical items from assigning Case? What is the relationship between Case and agreement? Are the rules of Case assignment the same across different alignment systems? We take up these issues in the next section.

\section{Explanations}

\subsection{Case assigners}

An ongoing issue in discussion of Case has been the distinction between Case-assigning and non-Case-assigning heads. In the preceding sections, we alluded to several such distinctions: between verbal predicates (which can, in some cases, assign Case to their complements) and adjectival predicates (which cannot); between finite inflectional heads (which can assign Case to their clausal subjects) and non-finite ones (which cannot); between active transitive verbs (which can assign Case to their complements) and passives (which cannot).

There have been attempts in the theoretical literature to derive at least some of these distinctions from deeper principles. Chomsky's (1981) dual binary-feature system, shown in Table 2, was one such attempt. On this account, the $[-\mathrm{N}]$ feature was the crucial property that allowed a category to be, in principle, an assigner of abstract Case. This explanation had the 
desirable effect of ruling in verbs and prepositions as Case assigners, and ruling out nouns and adjectives; however, it also faced many challenges. For instance, the status of inflectional categories such as finite Tense as Case assigners, despite their absence from the typology in Table 2, was problematic; equally inexplicable was the contrast between adjectives, which apparently universally fail to assign Case, and nouns, which assign genitive Case under certain circumstances. Essentially, it turned out that lexical categories were not fine-grained enough to capture both the necessary and sufficient conditions for the status of a head as a Case assigner (compare finite vs. non-finite Tense, active vs. passive verbs, etc.).

Table 2: Featural decomposition of lexical categories (Chomsky 1981)

\begin{tabular}{|l|l|l|}
\hline & $+\mathrm{N}$ & $-\mathrm{N}$ \\
\hline$+\mathrm{V}$ & adjective & verb \\
\hline$-\mathrm{V}$ & noun & preposition \\
\hline
\end{tabular}

Another important attempt to predict the distribution of Case assigners grew out of the Split VP Hypothesis - the idea that there is a functional head (often labeled $v^{0}$ ), distinct from the lexical verb, that is responsible for introducing the external argument, assigning accusative case to the object, and, perhaps, "verbalizing" the category-less lexical root (see Chomsky 1995; Hale and Keyser 1993; Kratzer 1996; Marantz 1997; among others). This hypothesis located the caseassigning capacity of verbs away from the verb itself, in $v^{0}$. The move allowed alternations such as the passive or the (anti-)causative to be viewed as variations in the verbal functional head; given that accusative case assignment was a property of this verbalizing head, it was natural that adjectives would lack this capacity. 
These newer approaches, however, still treated case itself as a sui generis syntactic feature. As noted in section 2, such attempts to reduce case to grammatical function (e.g. SUBJECT) run into significant empirical problems. More recently, Pesetsky and Torrego (2001, 2004, 2007) have proposed that case features are simply the uninterpretable counterparts of tense/aspect features, much as phi-features (person, number, gender) on tense/aspect/mood (TAM) markers or finite verbs are understood as the uninterpretable counterparts of phi-features on nominal projections.

\subsection{Case and agreement: a brief history of co-occurrence and causality}

One of the central empirical issues which has pervaded the literature on case is the relationship between case and agreement. ${ }^{9}$ Pre-theoretically, the most clear illustration of this relationship comes from the subjects of finite clauses: in a great many languages, such subjects obligatorily bear nominative case, and also obligatorily determine agreement on the finite verb or tense/aspect-marker. For example, in Latvian:

$\begin{array}{llll}\text { Bērn-s } & \text { zīmē } & \text { veikal-u } & \text { Latvian } \\ \text { child-NOM draw.3sG.PRES } & \text { store-ACC } \\ \text { 'The child is drawing a store.' } & \end{array}$

Within generative linguistics, this observation has been captured in different ways at different times. The Government \& Binding framework was able to capture the relationship between

\footnotetext{
${ }^{9}$ The term agreement should be understood here in the narrow sense, as morpho-phonologically overt co-variance between two morphosyntactic elements in one or more features of the set \{number, person, gender/noun-class\}.
} 
nominative case and finite agreement by ascribing a dual role to the $\mathrm{I}(\mathrm{nfl})^{0}$ node (Chomsky 1986; Mohanan 1982; Ouhalla 1991; Reuland 1983; Rizzi 1982; Stowell 1981, a.o.). Government by I was considered to be responsible for the assignment of nominative case, which (in at least a subset of nominative-accusative languages) was coupled with movement of the governed phrase to the specifier position of the inflectional projection.

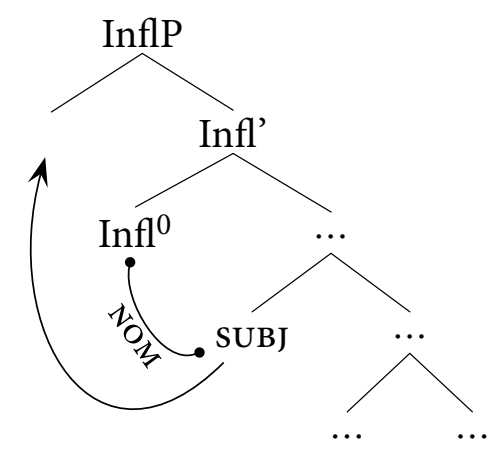

Additionally, the structural relationship between a head and its specifier-or spec-head, for short-was afforded a special status, in that it could give rise to the sharing (or checking) of values between the phrase in specifier position and the head of the entire projection.

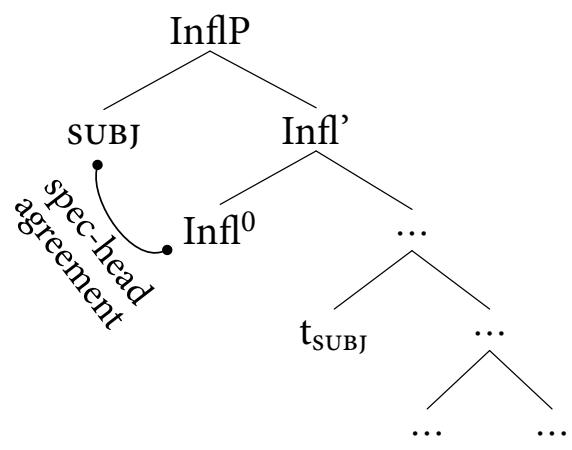

This dual role of $\mathrm{I}^{0}$ captured the observed coupling of nominative case and finite agreement. 
Notice that at this stage of theoretical development, no causal relationship between case and agreement was assumed; the phrase governed by $\mathrm{I}^{0}$ simply happened to be the one to move to [Spec, IP], which in turn determined finite agreement on $\mathrm{I}^{0}$. Thus, it was perfectly possible to have other sources of case assignment-e.g. inherent case assignment by of in English - that were associated with no agreement whatsoever.

The advent of the Minimalist Program (Chomsky 1995, et seq.) resulted in a subtle but important change in the logic of the case-agreement relationship. An increased interest in what "drove" certain syntactic operations led to the hypothesis that agreement was a fundamental need of the finite verb or tense/aspect-marker; this idea was reflected in the introduction of "uninterpretable features", elements of the derivation that would cause ill-formedness unless tended to by a particular syntactic operation. Agreement was construed as a response to the syntactic system's need to neutralize these uninterpretable features on the finite verb or tense/aspect-marker. This change in the theoretical treatment of agreement came with a concomitant change in the theory of case: the Case Filter was recast as an uninterpretable feature in its own right, which resided on noun phrases; it was assumed that this feature got "checked" precisely when the noun phrase in question entered into a full-fledged agreement relation with some syntactic head. ${ }^{10}$

\footnotetext{
${ }^{10}$ The qualifier full-fledged here is meant to distinguish agreement relations involving the full set of nominal features with relations involving only a subset of those features. This distinction is not crucial at the current juncture (although see below); for the purposes of the current discussion, it is sufficient to know that agreement between a finite verb or tense/aspect-marker and the subject is considered full-fledged.
} 


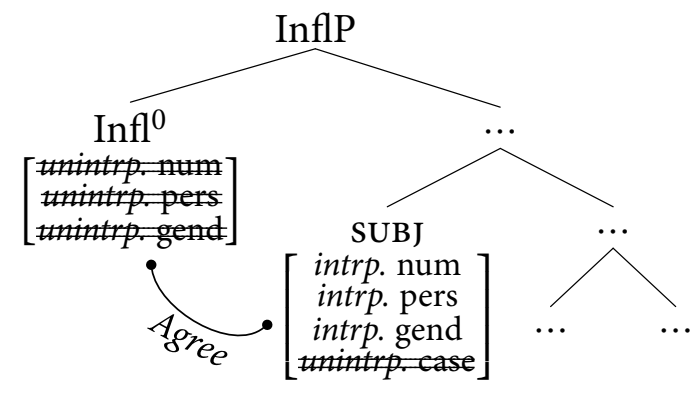

The choice of case assignment was understood to be fundamentally linked to the identity of the head with which the noun phrase entered its agreement relationship (nominative for $\mathrm{I}^{0}$, accusative for $\mathrm{V} / v^{0}$, and so forth).

The changes brought on by Minimalism created a much tighter coupling between case and agreement than had existed before. Consider the fate of a noun phrase that is not the subject of a finite clause. Under the GB treatment, this noun phrase needed to satisfy the Case Filter, and did so if it stood in the appropriate structural relation (i.e., government) with an appropriate heade.g., a preposition, or a verb capable of assigning accusative case. There was no requirement that this noun phrase enter an agreement relationship with any other syntactic element (though this was of course possible, if the language in question had agreeing prepositions and/or objectagreement). Under the MP treatment, however, no case assignment could exist without agreement: case assignment was now a "side effect" of a noun phrase entering into a full-fledged agreement relationship with a given head. Every overt noun phrase now needed an agreement relationship-observed or hypothesized - to explain how it could satisfy this new implementation of the Case Filter. 
This path was not the only conceivable one that could have been taken. Indeed, an alternative view was articulated almost concurrently with the publication of Chomsky's (1995) "Minimalist Program": ${ }^{11}$

[By] virtue of being licensed in situ by Case binders that are or contain functional heads, ergative and accusative arguments may agree with those heads. (Bittner and Hale 1996:3)

The view espoused by Bittner and Hale holds that it is the assignment of case to (at least some) noun phrases that allows those noun phrases to control agreement, and not the other way around. About a decade after Bittner and Hale's paper, this same view on agreement was defended in greater detail within an entirely different view of case assignment. Bobaljik (2008) revived a set of typological observation made by Moravcsik $(1974,1978)$, concerning the set of arguments that are eligible to be targeted for agreement in a given language. But while Moravcsik's observations were phrased in terms of grammatical functions ("subject", "object", "indirect object", "adverb"), Bobaljik demonstrated that the empirical coverage of those observations could be extended to cover ergative-absolutive languages and languages with 'quirky subjects' if the observations were phrased in terms of case marking, rather than grammatical functions.

The particular implementation adopted by Bobaljik cannot be properly illustrated without first discussing Marantz's (1991) configurational theory of case (see section 3.3); however, the crucial observation is that, in a given language, the case marking borne by a DP is a better predictor of that DP's agreement pattern than its grammatical function is. Left as is, this

\footnotetext{
${ }^{11}$ The opposition established in the text below is a very circumscribed one, pertaining to the causal relation between (some) case markings and (some) agreement relations; this should not be taken as an indication that Bittner and Hale (1996) were opposed to the Minimalist Program more generally. As the paper in question makes clear, these authors were working decidedly within the general framework espoused by Chomsky (1995).
} 
observation - much like the previously discussed correlation between nominative case and finite agreement-would amount to a statement about correlation rather than causation. However, Bobaljik demonstrated that, although bearing the "correct" case-marking is a necessary condition for agreement with a given noun phrase, it is not a sufficient condition; the agreement target must also be, structurally, the highest DP among those whose case qualifies them for agreement; furthermore, the agreement target must be sufficiently local to the head that agrees with it.

The observation that correct case marking is a necessary but insufficient condition for agreement crucially supports the view that assignment of case is a pre-condition to the calculus of agreement. This, of course, means that the MP view of case as a "side effect" of agreement is untenable; however, that view was in trouble independently of Bobaljik's observation (see, e.g., Preminger 2011 for a reduction of the view that absolutive in Basque arises via agreement, overt or otherwise).

Of course, for this new view of the interaction between case and agreement to be viable, there needs to be a theory of case assignment where case arises independently of (and prior to) agreement. Fortunately, this is provided by configurational approaches to case assignment, which we turn to next.

\subsection{The structural determination of case: head-centered vs. configurational approaches}

Since agreement has canonically been viewed as a relationship between a head and a phrase, the view of case as a by-product of agreement necessarily commits its proponents to the view that case likewise depends on the same structural relation. But in actuality, it is feasible to ponder the structural conditions on case and agreement separately. Specifically, we might reject the MPstyle causal link between agreement and case while maintaining an MP-style structural condition 
on case assignment, consisting of (i) a c-command relation obtaining between a designated head and the relevant noun phrase, and (ii) the absence of an intervening phase boundary or DP between the two.

This approach can be contrasted with what is known as a configurational system of case assignment. In the latter, noun phrases are assigned case by virtue of their structural position relative to certain lexical heads and, more importantly, to other noun phrases in the clause. Implementations of configurational case assignment differ (see Bittner and Hale 1996; Marantz 1991; Yip, Maling and Jackendoff 1987, inter alia), but all approaches share the insight that accusative and ergative (see section 1) can be given a unified treatment as dependent cases. While this insight is not entirely new, configurational approaches to case assignment take seriously the fact that both accusative and ergative are cases that typically depend on the presence of another, case-marked noun phrase in their local vicinity (see also Bobaljik 1993, Laka 1993). Configurational approaches allow these cases to arise directly by virtue of the presence of this other noun phrase; the difference between accusative and ergative alignments then reduces to a question of location of dependent case assignment (i.e., whether the dependent case is assigned to the higher or lower of the two relevant noun phrases).

Another crucial virtue of configurational approaches to case assignment is their ability to account for so-called 'quirky case' languages. In Icelandic, the normal nominative-accusative pattern of case assignment in the clause is disrupted under certain circumstances-specifically, when the particular predicate chosen idiosyncratically selects a subject with non-nominative case (e.g. dative, genitive, or accusative; see Zaenen, Maling and Thráinsson 1985, and much subsequent literature for arguments that despite being non-nominative, these arguments are indeed grammatical subjects). Interestingly, selection of a quirky subject inhibits the appearance 
of accusative on the direct object; the direct object surfaces with nominative case in these instances.

$$
\begin{array}{llll}
\text { Henni } & \text { líkuðu } & \text { hestarnir/*hestana. } & \text { Icelandic } \\
\text { she.DAT } & \text { liked.PL } & \text { horses-the.NOM.PL/*horses-the.ACC.PL }
\end{array}
$$

'She liked the horses.' (Thráinsson 2007:172)

Approaches to case that locate the ability to assign case in the functional infrastructure of the clause have a hard time accounting for the disappearance of the accusative; configurational approaches, on the other hand, handle these facts with ease.

\subsection{Case in ergative languages}

Case assignment in ergative languages, where the morphological case of the intransitive subject aligns with that of the transitive object, has posed particular challenges for Case theory. Currently, there are several families of approaches to this pattern of case assignment, which we survey below.

The first family of approaches is configurational (see also section 3.3). Under these approaches, the assignment (or "discharging") of ergative case is assumed to depend on some inherent morphosyntactic property of the clause in which the ergative case arises. In one variant of this approach, the Obligatory Case Parameter (Bobaljik 1993, Laka 1993), ergative case emerges only when the absolutive has already been discharged within the same clause. On this view, the distinction between ergative alignment and accusative alignment arises from a parameter which requires the obligatory discharging of either "subject case" or "object case" (the former setting giving rise to an accusative alignment, the latter to an ergative one). In another 
variant of the configurational approach, Marantz's (1991) theory of dependent case, the emergence of ergative case depends not on the discharge of the absolutive, but on the presence of a non-oblique nominal which is distinct from, and syntactically lower than, the ergative nominal. ${ }^{12}$ On this view, the parameter setting determines whether dependent case is assigned to the lower or higher of two distinct nominals (again, the former setting results in an accusative alignment and the latter in an ergative one).

The second family of analyses views the ergative as an inherent case. It is virtually uncontroversial that certain lexical heads in a given language place idiosyncratic requirements on the case borne by their arguments (cf. different cases assigned by different prepositions, as for example in German). If we take seriously the status of $v^{0}$ as a lexical head introducing the external argument (see discussion and references in section 3.1), then it is entirely possible that, in a given language, this lexeme would place the same sort of idiosyncratic case requirements upon the argument it introduces (i.e., the external argument). The result would be a particular case marking associated with the transitive subject, but not with the transitive object or the intransitive subject. The proposal that the ergative is assigned as an inherent case relies on two main types of evidence. First, in a number of ergative languages, the link between ergative case and the thematically agentive event participant seems quite strong; at least, it is stronger than the link between nominative case and the agent role. For instance, Laka (2006) argues for a strong connection between case and theta roles in Basque, which in turn favors the inherent-case

\footnotetext{
${ }^{12}$ The term distinct here is meant to preclude positions occupied by a moved nominal in the course of the syntactic derivation from counting as separate operands for the calculation of dependent case.
} 
approach to the ergative. ${ }^{13}$ The second argument in favor of treating the ergative as an inherent case comes from case preservation under raising (see Woolford 2006 for discussion and examples). ${ }^{14}$

Inherent case can be assigned to a DP directly by a verbal head, as suggested by Laka (2006), Legate (2008) and Aldridge $(2004,2008)$, among others. On the other hand, Markman and Graschenkov (2012) and Polinsky (in press) argue that the thematic role of the agent is assigned to the subject not by a verbal projection, but by a morphologically dependent adposition; the PP, in its entirety, is located in the specifier of the highest $v^{0}$, which accounts for the subject properties of the ergative expression. Assuming that adpositions assign inherent case (cf. Landau 2010), ${ }^{15}$ this brings the latter approach closer to that of Laka, Legate, and Aldridge. One of the challenges for the proposal that ergative is an inherent case lies in accounting for agreement patterns observed across ergative languages, which are far from uniform. Another dimension along which ergative languages differ has to do with the accessibility of the ergative expression to A-bar extraction under relativization, wh-question formation, or topicalization. Some ergative languages disallow such extraction for the ergative, but invariably permit it for the absolutive- a phenomenon known as "syntactic ergativity" (Manning 1996). Such differences in agreement and extraction patterns have led to the idea that the ergative languages do not constitute a uniform class. A number of recent approaches, most notably Legate (2008) and Aldridge (2004, 2008), pursue the idea that ergative languages fall into two distinct subtypes. In the first subtype,

${ }^{13}$ This analysis of Basque is not shared by all researchers—see Režać et al. (in press) for the proposal that the Basque ergative is a structural case.

${ }^{14}$ However Artiagoitia (2001) and Režać et al. (in press) show that under raising, the ergative in Basque patterns as a structural case.

${ }^{15}$ This assumption is not uncontroversial, but for reasons of space, we will not expand on it here. 
the absolutive corresponds to the nominative case, and is assigned to the intransitive subject and the direct object by $\mathrm{T}$; the ergative is treated as an inherent case. In these languages, only intransitive subjects can appear in control infinitives, the ergative is not accessible to A-bar movement, and agreement is determined by the absolutive DP. Examples of such languages include Seediq, Inuit, and Chukchi. In the second subtype, absolutive case is seen as a morphological default, inserted when a dedicated morphological realization is unavailable for a given abstract case. Intransitive subjects receive nominative Case and direct objects receive accusative Case, but the morphology of these cases is identical and its surface form is what we have come to call 'absolutive'. These languages use only the absolutive for DPs without dedicated abstract Case (e.g. hanging topics); since the morphological absolutive can appear on DPs marked with abstract Cases other than absolutive (lacking a distinct morphological form of their own), multiple absolutives can appear in a single clause. Finally, subject agreement in these languages may be triggered by all subjects, by the intransitive subject alone, or by the highest DP with structural Case (this last pattern is sometimes known as absolutive agreement). This subclass of ergative languages does not manifest syntactic ergativity-e.g., it does not impose extraction restrictions on the ergative argument.

\section{Summary}

In this chapter, we have presented and discussed the notions of morphological (surface) case and abstract Case, showing the empirical and theoretical motivation for each. The discussion of morphological case presented the dimensions of cross-linguistic variation found in this domain, and surveyed main tendencies in the expression of case. Although significant variation is found in the expression of morphological case, this variation is constrained by certain limitations and tendencies, which we have attempted to outline. The notion of abstract Case is used to predict the 
distribution of overt and non-overt nominal forms, and is considered one of the fundamental abstract syntactic relations in linguistic theory. The main role of abstract Case is in constraining the distribution of various types of nominals. Accordingly, the formalization of abstract Case is an important task for modern linguistic theory.

\section{Further readings (ordered chronologically)}

Jakobson, Roman. 1936. Beitrag zur allgemeinen Kasuslehre: Gesamtbedeutung der russischen Kasus. Reprinted in: Roman Jakobson. 1971. Selected writings: Word and language, II, vol. 2, 23-71. Berlin: Mouton de Gruyter.

Fillmore, Charles. 1968. The case for case. In Universals in linguistic theory, eds. Emmon Bach and Robert T. Harms, 1-88. New York: Holt, Rinehart, and Winston.

Williams, Edwin. 1994. Thematic structure in syntax. Cambridge, Mass.: MIT Press.

Bobaljik, Jonathan David \& Susi Wurmbrand. 2008. Case in GB/Minimalism. In Oxford handbook of case, eds. Andrej Malchukov and Andrew Spencer, 44-58. Oxford: Oxford University Press.

Sigurðsson, Halldór Ármann. 2012. Minimalist C/case. Linguistic Inquiry 43, 191-227.

\section{Acknowledgments}

The work presented here was supported in part by grants from the Center for Advanced Study of Language at the University of Maryland and from NSF (grant BCS-1144223) to the first author. Any opinions, findings and conclusions or recommendations expressed in this material are those of the authors and do not necessarily reflect the views of any agency or entity of the United States Government. We are solely responsible for any errors in this chapter.

\section{References}

Aldridge, Edith. 2004. Ergativity and word order in Austronesian languages. Ph.D. Dissertation, Cornell University.

Aldridge, Edith. 2008. Generative approaches to ergativity. Language and Linguistics Compass $5,966-995$. 
Artiagoitia, Xabier. 2001. Seemingly ergative and ergatively seeming. In Features and interfaces in Romance: essays in honor of Heles Contreras, eds. Julia Herschensohn, Enrique Mallen and Karen Zagona, 1-22. Amsterdam: John Benjamins.

Baker, Mark C. 2008. The syntax of agreement and concord. Cambridge: Cambridge University Press.

Bejar, Susana, and Diane Massam. 2002. Multiple case checking. Syntax 2, 65-79.

Bittner, Maria, and Kenneth Hale. 1996. The structural determination of case and agreement. Linguistic Inquiry 27, 1-68.

Blake, Barry. 2001. Case. 2 ed. Cambridge: Cambridge University Press.

Bobaljik, Jonathan. 1993. On ergativity and ergative unergatives. MIT Working papers in Linguistics 19, 45-88.

Bobaljik, Jonathan. 2008. Where's phi? Agreement as a post-syntactic operation. In Daniel Harbour, David Adger, and Susana Bejar (eds.). Phi-Theory: Phi features across interfaces and modules, 295-328. Oxford: Oxford University Press.

Bobaljik, Jonathan David and Idan Landau. 2009. Icelandic Control is not A-movement: the case from Case. Linguistic Inquiry 40:113-132, doi: 10.1162/ling.2009.40.1.113.

Chomsky, Noam. 1981. Lectures on government and binding. Dordrecht: Foris.

Chomsky, Noam. 1986. Knowledge of language: Its nature, origins, and use. New York: Praeger.

Chomsky, Noam. 1995. The minimalist program. Cambridge, MA: MIT Press.

Chomsky, Noam, and Howard Lasnik. 1977. Filters and control. Linguistic Inquiry 8, 425-504.

Comrie, Bernard. 1978. Ergativity. In Winifred Lehmann (ed.). Syntactic typology: Studies in the phenomenology of language, 329-394. Austin: University of Texas Press. 
Comrie, Bernard. 1989. Language universals and linguistic typology. 2 ed. Chicago: University of Chicago Press.

Comrie, Bernard, and Maria Polinsky. 1998. The great Dagestanian case hoax. In Anna Siewierska and Jae Jung Song (eds.) Case, typology, and grammar, 95-114. Amsterdam: John Benjamins.

Coon, Jessica. 2013a. TAM split ergativity. Part I. Language and Linguistics Compass 7, 171190.

Coon, Jessica. 2013a. TAM split ergativity. Part II. Language and Linguistics Compass 7, 191200.

Dixon, R.M.W. 1994. Ergativity. Cambridge: Cambridge University Press.

Gerdts, Donna, and Cheong Youn. 1988. Korean psych constructions: Advancement or retreat? In Lynn MacLeod, Gary Larson and Diane Brentari (eds.). Papers from the 24th Annual Regional Meeting of the Chicago Linguistic Society, Part One: The General Session,155175. Chicago: Chicago Linguistic Society.

Hale, Kenneth, and Samuel Jay Keyser. 1993. On argument structure and the lexical expression of syntactic relations. In Kenneth Hale and Samuel Jay Keyser (eds.). The view from Building 20: Essays in linguistics in honor of Sylvain Bromberger, 53-110. Cambridge: MIT Press.

Henry, Alison. 1995. Belfast English and Standard English. Oxford: Oxford University Press. Iggesen, Oliver. 2011. Number of cases. In Matthew S. Dryer and Martin Haspelmath (eds.). World atlas of language structures. Munich: Max Planck Digital Library. Kratzer, Angelika. 1996. Severing the external argument from its verb. In Johan Rooryck and Laurie Zaring (eds.). Phrase structure and the lexicon, 169-196. Dordrecht: Kluwer. 
Laka, Itziar. 1993. Unergatives that assign ergative and unaccusatives that assign accusative. In Jonathan Bobaljik and Colin Phillips (eds.). Papers on case and agreement I, 149-172. (MITWPL 18.)

Laka, Itziar. 2006. On the nature of case in Basque: structural or inherent? In Hans Broekhuis, Norbert Corver, Riny Huybregts, Ursula Kleinhenz, and Jan Koster (eds.). Organizing grammar: Linguistic studies in honor of Henk van Riemsdijk, 374-382. Berlin—New York: Mouton de Gruyter.

Landau, Idan. 2010. The locative syntax of experiencers. Cambridge, MA: MIT Press.

Lasnik, Howard. 2008. On the development of Case theory: Triumphs and challenges. In Robert Freidin, Carlos P. Otero, and Maria Luisa Zubizarreta (eds.). Foundational issues in linguistic theory: Essays in honor of Jean-Roger Vergnaud, 17-41. Cambridge, MA: MIT Press.

Legate, Julie Anne. 2002. Warlpiri: Theoretical implications. Ph.D. Dissertation. MIT.

Legate, Julie A. 2008. Morphological and abstract case. Linguistic Inquiry 39, 55-101. Manning, Christopher. 1996. Ergativity. Stanford: CSLI.

Marantz, Alec. 1991. Case and licensing. In Germán Westphal, Benjamin Ao, and Hee-Rahk Chae (eds.) Eastern States Conference on Linguistics, 234-253. Cornell University, Ithaca, NY: Cornell Linguistics Club.

Marantz, Alec. 1997. No escape from syntax: don't try morphological analysis in the privacy of your own lexicon. In Proceedings of the 21st Penn Linguistics Colloquium (PLC 21), eds. Alexis Dimitriadis, Laura Siegen, Clarissa Surek-Clark and Alexander Williams, vol. 4.2, University of Pennsylvania Working Papers in Linguistics, Philadelphia, PA: Penn Linguistics Club, 201-225. 
Markman, Vita, and Pavel Graschenkov. 2012. On the adpositional nature of ergative subjects. Lingua 122, 257-266.

McCreight Young, Katherine. 1988. Multiple case assignments. Ph.D. Dissertation, MIT.

Mohanan, K. P. 1982. Infinitival subjects, government, and abstract Case. Linguistic Inquiry 13, $323-327$.

Moore, John, and David Perlmutter. 2000. What does it take to be a dative subject? Natural Language and Linguistic Theory 18, 373-416.

Moravcsik, Edith A. 1974. Object-verb agreement. In Working papers on language universals, vol. $15,25-140$.

Moravcsik, Edith A. 1978. Agreement. In Universals of human language IV: syntax, ed. Joseph H. Greenberg, 331-374. Stanford, CA: Stanford University Press.

Ouhalla, Jamal. 1991. Functional categories and parametric variation. London: Routledge.

Owens, Jonathan. 1985. A grammar of Harar Oromo (Northeastern Ethiopia): Including a text and a glossary. Hamburg: Buske Verlag.

Pesetsky, David and Esther Torrego. 2001. T-to-C movement: causes and consequences. In Ken Hale: a life in language, ed. Michael Kenstowicz, 355-426. Cambridge, MA: MIT Press.

Pesetsky, David and Esther Torrego. 2004. Tense, Case, and the nature of syntactic categories. In The syntax of time, eds. Jacqueline Gueron and Jacqueline Lecarme, 495-537. Cambridge, MA: MIT Press.

Pesetsky, David and Esther Torrego. 2007. The syntax of valuation and the interpretability of features. In Phrasal and clausal architecture: syntactic derivation and interpretation, In honor of Joseph E. Emonds, eds. Simin Karimi, Vida Samiian and Wendy Wilkins, 262294. Amsterdam: John Benjamins. 
Polinsky, Maria. In press. A tale of two ergatives.

Postal, Paul. 1974. On raising: One rule of English grammar and its theoretical implications. Cambridge: MIT Press.

Preminger, Omer. 2011. Asymmetries between person and number in syntax: A commentary on Baker's SCOPA. Natural Language and Linguistic Theory 29, 917-937.

Radford, Andrew. 2004. English syntax: An introduction. Cambridge: Cambridge University Press.

Reuland, Eric. 1983. Governing -ing. Linguistic Inquiry 14, 101-136.

Režać, Milan, Pablo Albizu and Ricardo Etxepare. In press. The structural ergative of Basque and the theory of case. Natural Language and Linguistic Theory.

Richards, Norvin. 2013. Lardil "case stacking" and the timing of case assignment. Syntax 16, 4276.

Rizzi, Luigi. 1982. Issues in Italian syntax. Dordrecht: Foris.

Schütze, Carson. 2001. On Korean "Case stacking": The varied functions of the particles $k a$ and lul. The Linguistic Review 18: 193-232.

Sigurđsson, Halldór A. 2002. To be an oblique subject: Russian vs. Icelandic. Natural Language and Linguistic Theory 20, 691-724.

Silverstein, Michael. 1976. Hierarchy of features and ergativity. In R.M.W. Dixon (ed.). Grammatical categories in Australian languages, 112-171. Canberra: Australian National University Press.

Stowell, Timothy. 1981. Origins of phrase structure. Ph.D. Dissertation, MIT.

Szabolcsi, Anna. 2009. Overt nominative subjects in infinitival complements in Hungarian. In 
Marcel den Dikken and Robert Vago (eds.). Approaches to Hungarian, vol. 11: Papers from the 2007 New York Conference, 251-276. Amsterdam: John Benjamins.

Thráinsson, Höskuldur. 2007. The syntax of Icelandic. Cambridge: Cambridge University Press.

Vergnaud, Jean-Roger. 1977. Letter to Noam Chomsky and Howard Lasnik on "Filters and control”. Reprinted in: Robert Freidin, Carlos P. Otero, and Maria Luisa Zubizarreta (eds.). 2008. Foundational issues in linguistic theory: Essays in honor of Jean-Roger Vergnaud, 3-15. Cambridge, MA: MIT Press.

Woolford, Ellen. 2006. Lexical case, inherent case, and argument structure. Linguistic Inquiry $37,111-130$.

Yip, Moira, Joan Maling and Ray Jackendoff. 1987. Case in tiers. Language 63:217-250.

Zaenen, Annie, Joan Maling and Höskuldur Thráinsson. 1985. Case and grammatical functions: the Icelandic passive. Natural Language and Linguistic Theory 3:441-483. 


\author{
Maria Polinsky \\ Department of Linguistics \\ Harvard University \\ Cambridge, MA 02138 \\ polinsky@fas.harvard.edu \\ Omer Preminger \\ Department of Languages, Literatures, and Linguistics \\ 340 H.B. Crouse Hall \\ Syracuse University \\ Syracuse, NY 13244-1160 \\ opreming@syr.edu
}

